\title{
Optimization of Masking Process of Steel Tube During Atmospheric Plasma Spraying, for Use in Serial Production
}

\author{
Jozef Kužma ${ }^{1}$, Michal Krescanko ${ }^{2}$, David Goldyniak ${ }^{1}$, Akash Nag ${ }^{2}$ \\ ${ }^{1}$ Technical University of Košice, Faculty of Manufacturing Technologies with a seat in Prešov, Bayerova 1, \\ 08001 Prešov, Slovak Republic \\ ${ }^{2}$ Indian Institute of Technology Dhanbad, India
}

\begin{abstract}
This study deals with the influence of selected technological factors on hardness, surface quality and topography of substrates after 24 layers of NiCr plasma was self-peeled off. The paper also deals with frequency of self-peeling the layers and the SEM observation of the deposited layers and substrates. Presented procedures and experimental results demonstrate changes and resistance of individual materials after an application of 24 plasma coatings. Samples from materials duralumin, chromium steel and material with the coating $\mathrm{Ni}-\mathrm{Cu}-\mathrm{Ni}$ were tested. The least impact for surface changes of substrate had samples from chromium steel. For this reason, chromium steel samples were also tested and compared for self-peeling frequency with respect to the number of coating layers and angle of surface. The main objective of this work was to select material, angle of plasma spraying and surface cleanliness that will show the least change in hardness and roughness after multiple plasma spraying with respect to the longest life of the cover mask. Cover mask is necessary for covering required areas of steel tube that must not be affected by plasma spraying, for use in serial production.
\end{abstract}

Keywords - Optimization, 24-time plasma spraying, lifetime, cover mask, steel tube

DOI: $10.18421 /$ TEM92-13

https://doi.org/10.18421/TEM92-13

Corresponding author: Jozef Kužma,

Technical University of Košice, Faculty of Manufacturing

Technologies with a seat in Prešov, Bayerova 1, 08001

Prešov, Slovak Republic.

Email: jozefkuzma69@gmail.com

Received: 27 March 2020.

Revised: 21 April 2020.

Accepted: 28 April 2020.

Published: 27 May 2020.

(cc)BY-NC-ND (C) 2020 Jozef Kužma at al; published by UIKTEN. This work is licensed under the Creative Commons Attribution-NonCommercial-NoDerivs 3.0 License.

The article is published with Open Access at www.temjournal.com

\section{Introduction}

After 1950, technology of plasma coating was developed as surface finishing. This technology is widely used in the field of engineering, electrical engineering, aerospace and automotive [1]. This technology is one of the top for spraying a relatively thick layers (several hundred micrometers) to upgrade parameters of surface substrate. Their extensive use in industrial practice is the main motivation for development of new coatings and rationalizing process [2]. Of the various ways of applying thermally sprayed coatings, technology of plasma-spraying is at the forefront. Technology of plasma spraying allows its application on practically all technically useful materials, both metallic and non-metallic substrates. Metal or ceramic coatings can also be applied. Metallic additives are steel-based materials with the higher carbon content (up to $0.4 \% \mathrm{C})$ and chromium $(13 \% \mathrm{Cr}, 17 \% \mathrm{Cr})$. Pure metals as $\mathrm{Fe}, \mathrm{Al}, \mathrm{Cu}, \mathrm{Cr}, \mathrm{Ni}$, are also used in small quantities [3].

Metallic layers have specific properties as abrasion resistance, temperature resistance, and mainly high hardness [4]. These specific properties improve surface properties of components for required production conditions. It leads to a longer life-time and increase the component reliability [5]. One of the most important factors, which affect characteristics and durability of coatings is their adhesion to the surface of substrate [6]. It is possible to achieve high level of adhesion by different type of coating technology, composition of substrate material, composition of spraying layer or properties of substrate surface [7], [8]. The mechanical anchoring of incident particles on substrate surface is one of the next properties, which have effect on adhesion of the coating layer to the substrate surface [9]. Assessment of coating strength carried out is performed by strength of the joint between new and stiff particles. In general, for all thermally sprayed coatings, adhesion to the substrate decreases with increasing thickness of the coating layer [10]. 
Coating properties are affected by three interdependent sub-systems: 1. Plasma jet formation (set parameters) [11], 2. Powder material in plasma jet and mixing with surrounding gas [12], 3. Impact of particles and their solidification on substrate surface [13].
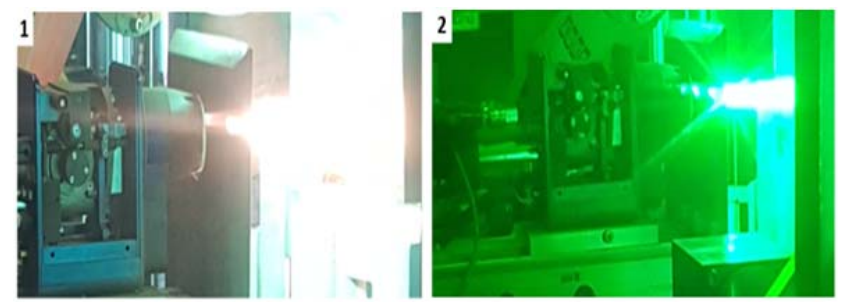

Figure 1. Plasma spraying; 1 - real image, 2 - real image through protective glass

Most of the previous research [9], [13] of plasma spraying was focused on the investigation of layer properties [14]. Problem of optimization (rationalization) of covering product areas which must not be affected by plasma spraying needs to be resolved, for use in serial production, because information or research about this problem are not available in the literature. Currently for the masking process, masking tapes are commonly being used. A lot of different types of masking tapes are available, but this technique is very time consuming and expensive, because in this case it is needed to be handmade. So, this technology is not suitable for conditions of serial production. Primary problem of optimization / rationalization of covering process of product areas which must not be affected by plasma spraying, for use in serial production has not yet been sufficiently investigated.

This manuscript was inspired by previous work "Change of the substrate surface after removal multiple plasma spraying layers" [18]. 12-times plasma spraying was used. It was first a selection of suitable materials for cover mask from 8 tested materials (not all tested materials were listed in the work, because some of them were damaged by plasma spraying). This work was the first step in investigation of the topic "Optimization of masking process of substrate before plasma spraying for use in conditions of serial production".

Next step of the investigation is the current manuscript "Optimization of masking process of steel tube during atmospheric plasma spraying, for use in serial production". New and more precise measurements and methods were used for this manuscript, and this article is more focused on the investigation of chromium steel. Values of measurement from the first article were not used here. Similar measurements were performed again.
The present study is focused on selected technological factors of hardness, surface quality and topography of substrates after self-peeling of coating layers after the application of 24 layers of $\mathrm{NiCr}$ by plasma spraying. The surface of substrate was analyzed using parameters of roughness and hardness, which were measured before and after plasma spraying. The least impact for surface changes of substrate had samples from chromium steel. For this reason, stainless steel samples were also tested and compared for self-peeling frequency with respect to the number of coating layers and angle of plasma spraying. The paper also contains several SEM observations of the deposited layers.

The lifetime of the cover mask is determined by changes in the internal dimensions, which are influenced by the thickness of the coating layer after multiple plasma spraying. The average coating thickness on the mask after one plasma spray is approx. $13.5 \mu \mathrm{m}$. After 06-10 spraying cycles, when the layer thickness is approx. $100 \mu \mathrm{m}$, the multi-layer started to self-peel. The process is repeated until the roughness of the cover mask is so high that the selfpeeling of the multilayer begins too late, in time when the thickness of the multilayer is higher than $250 \mu \mathrm{m}$. This process negatively affects the inner dimensions of the cover mask, reducing them. The reduced inner dimensions of the mask result in an incorrect dimension of the area which must not be coated. Therefore, it is very important to use material and design of the cover mask that has the best resistance to change of the roughness and hardness after multiple self-peelings of the multiple plasma layers. The hardness of the material directly affects the change in surface roughness and the roughness directly affects the frequency of self-peeling of multi layers. The frequency of self-peeling of the multi layers directly affects the dimensions of the area on the steel tube which must not be coated (Fig. 2.). The aim is the mask to have no negative effects on the dimensions of the masked areas on the tube outside the allowable tolerance even after 1000 spraying cycles.

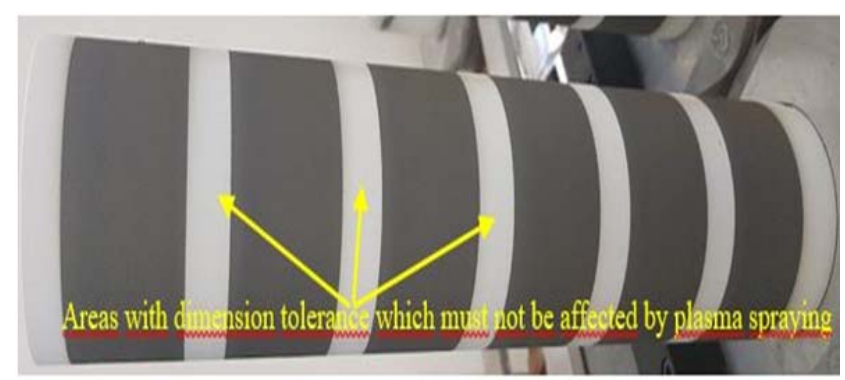

Figure 2. Areas on tube with dimension tolerance, which must not be affected by plasma spraying 


\section{Materials and Methods}

In this section were presented:

- Tested materials,

- Experimental conditions.

\subsection{Tested Materials}

At the beginning of the study, several types of available materials (Ceramic, Superdural, Teflon, Alloy plus, Hard coat, S Green, Nickel, Chromium steel, etc.) were selected for the production of the cover mask. After the initial tests, most of the materials were damaged or unusable. Following materials were qualified for the extended tests:

AlCu4Mg1 or Duralumin (STN 424203) - Tensile strength: 200-450 $\mathrm{MPa}$. Material properties: high strength after heat treatment, low corrosion resistance, good welding ability. The use of: production of medium and heavy duty components which require long time life as parts of aircrafts or vehicles.

Coated Ni-Cu-Ni material - Tensile strength: 275$550 \mathrm{MPa}$. Material properties: this surface treatment is used for final finish surface of $\mathrm{NdFeB}$ magnets. Final layer is formed by the first Ni-layer, second $\mathrm{Cu}$-layer and the third, final Ni-layer. Overall thickness of the coated layer is approx. $13 \mu \mathrm{m}$.

Steel 17029 or Chromium steel (STN 41 7029) Tensile strength: $\max 780 \mathrm{MPa}$. Material properties: high hardness and microhardness, stainless steel. The use of: production of kitchen knives, medical instruments, parts of machine tools [15], [16].

\subsection{Experimental Conditions}

Plasma spraying was realized by the plasma spraying device from GTV company, real image is shown in Fig. 1. Table 1. Shows the settings of plasma spraying. Twenty-four coating layers of $\mathrm{NiCr}$ were applied to the substrate. The evaluation was done after application of twenty-four coating layers. Used powder has chem. composition $\mathrm{Ni} 80 \%$ and $\mathrm{Cr}$ $20 \%$. Particles from plasma spraying reached a temperature of about $1450^{\circ} \mathrm{C}$. The dimension of the substrate to plasma jet was set to $190 \mathrm{~mm}$. The processes of grinding and polishing were used for preparing of substrate surfaces from Duralumin (AlCu4Mg1). Measurement values of uncoated samples are shown in Table 3.

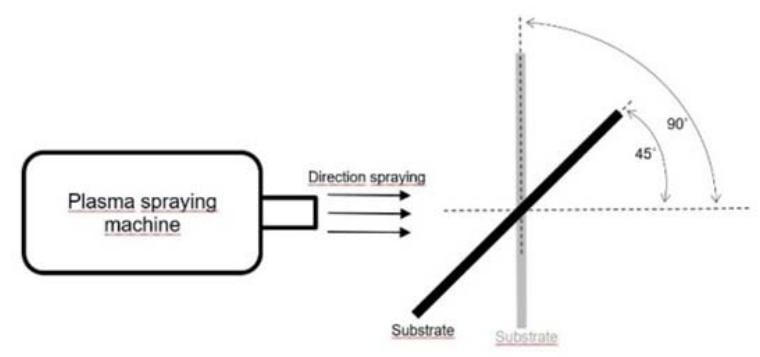

Figure 3. View angle of (surface) spraying to the substrate

The chemical compositions of the materials were measured on a Spectrometer ED-XRF X-ray device. The chemical compositions of materials are shown in Table 2. Surface roughness measurement and cross section [17] inspection was performed on Leica DFC 295microscope. The measurement of the microhardness of the materials was realized on Duramin40. Mean values of microhardness were calculated from the 3 measurements (imprints). Two versions of spraying angle $\left(90^{\circ}\right.$ and $\left.45^{\circ}\right)$ for each type of material (shown in Fig.3.) were used, and also versions with degreased and greased surface. The spraying angles were selected to verify the theory that the $45^{\circ}$ angle has a positive effect on the life of the cover mask. Vaseline film (thin layer) was used to create a grease surface. The film was prepared using Shell Gadus S2 V220ACvaseline. All measurement machines and processes which were used for experiments are shown in Fig. 4.

Table 1.Settings of plasma spraying

\begin{tabular}{|c|c|}
\hline Voltage / V & 150 \\
\hline Current / A & 345 \\
\hline Power / kW & 55 \\
\hline $\mathrm{Ar} /(\mathrm{L} / \mathrm{min})$ & 45,5 \\
\hline $\mathrm{Gas}$ flow \\
$\mathrm{H} /(\mathrm{L} / \mathrm{min})$ & 12,5 \\
\cline { 2 - 2 }
\end{tabular}

Table 2.Chemical composition of used substrates

\begin{tabular}{|c|c|c|c|c|c|c|c|c|c|c|c|c|c|}
\hline \multirow{2}{*}{$\begin{array}{c}\text { Sample } \\
\text { no. }\end{array}$} & \multirow{2}{*}{ Material } & \multirow{2}{*}{$\begin{array}{c}C T E \\
\left(m / \frac{m \cdot K}{10-6)} x\right.\end{array}$} & \multicolumn{11}{|c|}{ Chemical composition of used substrates (\%) } \\
\hline & & & $\mathrm{Al}$ & $\mathrm{Cu}$ & $\mathrm{Cr}$ & $\mathrm{Ni}$ & $\mathrm{Fe}$ & $\mathrm{Mg}$ & $\mathrm{Mn}$ & $\mathrm{Si}$ & $\mathrm{Zn}$ & $\mathrm{V}$ & $\mathrm{Ti}$ \\
\hline $1-5$ & Duralumin & 23 & 93,48 & 4,35 & - & - & 0,35 & 0,88 & 0,46 & 0,41 & 0,062 & - & - \\
\hline $6-10$ & $\mathrm{Ni}-\mathrm{Cu}-\mathrm{Ni}$ & 13 & 1,02 & 28,57 & 0,64 & 67,31 & 1,28 & - & 0,38 & $\mathrm{v}$ & - & 0,57 & 0,11 \\
\hline $11-15$ & Chromium steel & 12,6 & - & - & 13,02 & 0,29 & 85,97 & - & 0,31 & 0,29 & - & - & - \\
\hline
\end{tabular}




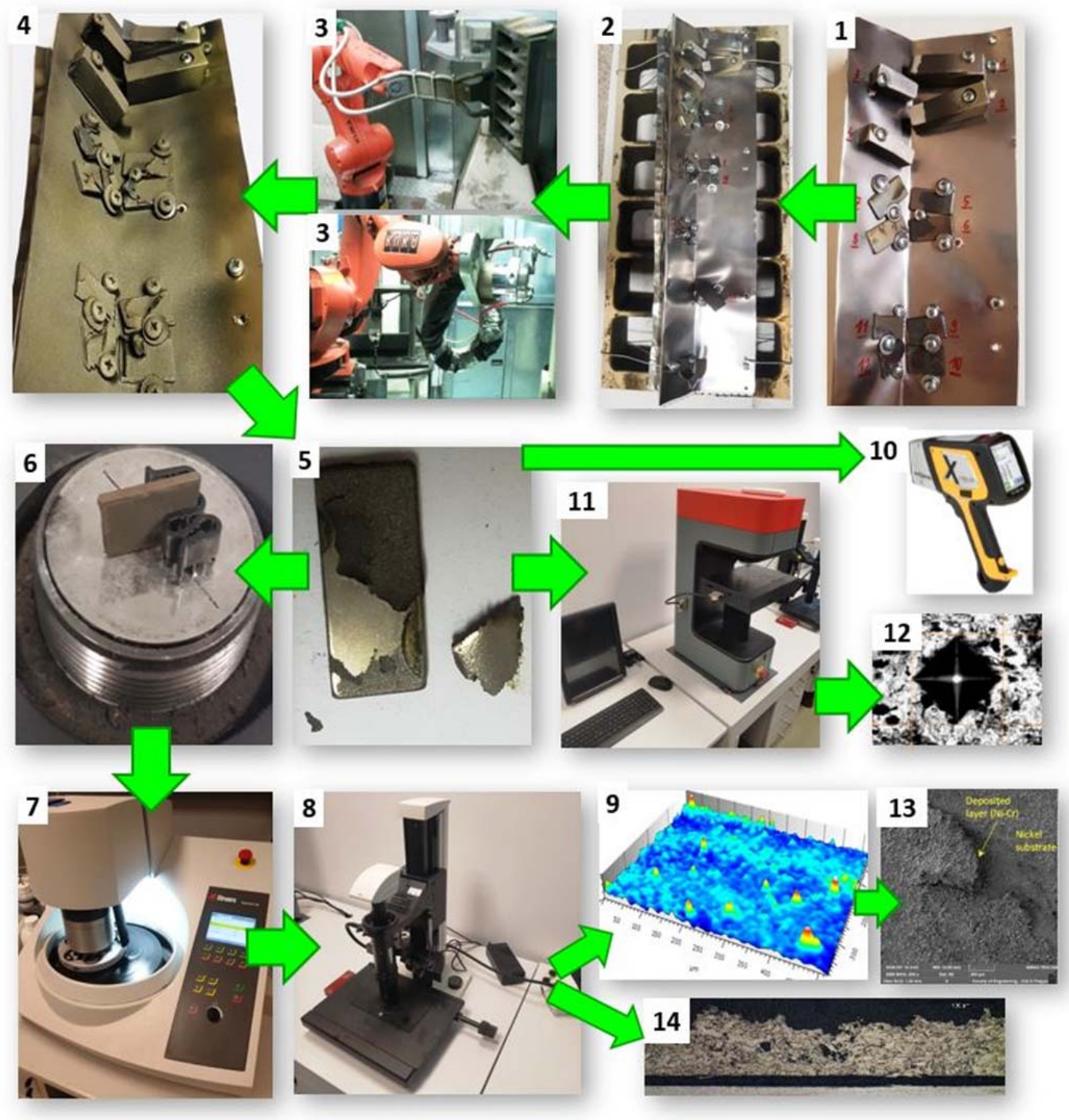

Figure 4. View of the experiment workflow: 1.Samples before 24-times plasma coating, 2.Samples fixed on the mask, 3. GTV plasma spraying machine, 4.Samples after plasma coating, 5.Sample with self-peeled off multilayer, 6.Preparation of samples for testing, 7. Grinding and polishing samples, 8.Leica DFC 295, 9.Samples evaluation of roughness, 10.Spectrometer ED-XRF, 11.Duramin-40, 12.Samples evaluation of HVm, 13.SEM observation of the deposited layers, 14.Samples evaluation of self-peel off layers

Description of the experiment process: first, samples were prepared by grinding and polishing to a roughness of $\mathrm{Ra}$ of $0.02-0.17 \mu \mathrm{m}$. To create a grease surface on samples, a thin Vaseline film was used. Then samples were fixed to the plate in the required angle, plates were fixed to the old version of covering mask. In next step, old version of covering mask with samples was installed to the automatic robot arm and twenty-four coating layers of the $\mathrm{NiCr}$ were applied to the samples by a GTV plasma spraying machine. In next step, the mask with plates and samples were removed from GTV plasma spraying machine and samples were unfixed from plate. Then samples were tested and measured for microhardness with the device Duramin40, for roughness with the microscope Leica DFC 295. The chemical compositions of the materials were measured with a Spectrometer ED-XRF X-ray device. The last step was SEM observation of samples and measurement and comparison of selfpeel off layers from samples.

\section{Results and Discussion}

Comparison of surface roughness $\mathrm{Sa}, \mathrm{Sz}$ and evaluation of microhardness based on HVmmin, HVmmax and HVmavg values are shown in Table 3.Comparison of the roughness is shown in Fig. 6.Measurement of the parameter Sa and surfaces of all tested materials are shown in Fig. 7-9. Comparison of all tested materials for the parameter $\mathrm{HVm}$ is shown in Fig. 10. Measurements of the parameter HVm are shown in Fig. 11-13. 
Table 3.Parameters of substrate surfaces before and after self-peeled off coating layers (highlighted are the compared parameters and the most suitable selected variant)

\begin{tabular}{|c|c|c|c|c|c|c|c|c|}
\hline $\begin{array}{c}\text { Sample } \\
\text { no. }\end{array}$ & Material & Angle of surface & $\begin{array}{c}\text { Surface } \\
\text { cleanliness }\end{array}$ & $\begin{array}{c}S a \\
(\mu \mathrm{m})\end{array}$ & $\frac{H V m}{a v g}$ & $\frac{H V m}{\min }$ & $\frac{H V m}{\max }$ & $\underset{(\mu \mathrm{m})}{\mathrm{Sz}}$ \\
\hline 1 & \multirow{5}{*}{ 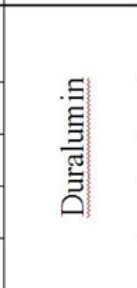 } & $\begin{array}{c}\text { before plasma } \\
\text { spr. }\end{array}$ & degrease & 0,02 & 128,62 & 125,84 & 131,39 & 0,31 \\
\hline 2 & & $90^{\circ}$ & degrease & 0,33 & 110,27 & 109,30 & 111,30 & 7,90 \\
\hline 3 & & $90^{\circ}$ & grease & 1,14 & 117,90 & 114,10 & 125,11 & 18,10 \\
\hline 4 & & $45^{\circ}$ & degrease & 0,31 & 96,30 & 95,80 & 97,00 & 9,00 \\
\hline 5 & & $45^{\circ}$ & grease & 0,38 & 97,70 & 92,60 & 103,70 & 11,40 \\
\hline 6 & \multirow{5}{*}{$\begin{array}{l}z \\
3 \\
\vdots \\
-1 \\
z\end{array}$} & $\begin{array}{c}\text { before plasma } \\
\text { spr. }\end{array}$ & degrease & 0,17 & 335,17 & 312,23 & 350,89 & 1,99 \\
\hline 7 & & $90^{\circ}$ & degrease & 0,77 & 183,80 & 177,20 & 194,30 & 17,50 \\
\hline 8 & & $90^{\circ}$ & grease & 0,58 & 189,80 & 180,60 & 195,70 & 17,10 \\
\hline 9 & & $45^{\circ}$ & degrease & 0,46 & 170,20 & 168,90 & 171,80 & 12,70 \\
\hline 10 & & $45^{\circ}$ & grease & 0,44 & 184,40 & 183,60 & 185,50 & 8,40 \\
\hline 11 & \multirow{5}{*}{ 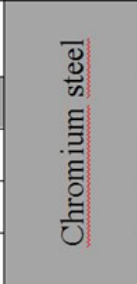 } & $\begin{array}{c}\text { before plasma } \\
\text { spr. }\end{array}$ & degrease & 0,07 & 676,12 & 699,18 & 678,91 & 0,39 \\
\hline 12 & & $90^{\circ}$ & degrease & 0,17 & 560,40 & 550,10 & 579,70 & 4,30 \\
\hline 13 & & $90^{\circ}$ & grease & 0,43 & 535,50 & 530,30 & 543,30 & 10,78 \\
\hline 14 & & $45^{\circ}$ & degrease & 0,20 & 486,60 & 482,60 & 494,20 & 5,80 \\
\hline 15 & & $45^{\circ}$ & grease & 0,28 & 474,30 & 552,60 & 593,70 & 5,60 \\
\hline
\end{tabular}

\subsection{Roughness}

Measurements were performed on the surfaces of samples after removing the coating layers and with the Leica DFC 295microscope. Samples were compared with 2D and 3D topography, but the best views of differences between samples are on the color 3D images. From these images are differences of roughness between samples easily recognizable and comparable. Black and white $2 \mathrm{D}$ and $3 \mathrm{D}$ views provide a real view of substrate surface. At 3D color views, red color shows high peaks of roughness and blue and dark blue show low peaks of roughness. An example of this scale is shown in Fig.5.

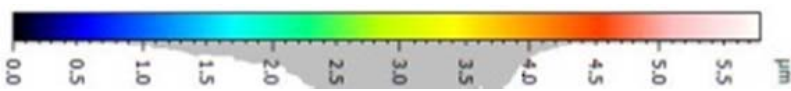

Figure 5. Colour scale of $3 D$ view of roughness

Measurements of parameter $\mathrm{Sa}$ and surfaces of all tested materials are shown in Fig. 7-9.Comparison of all measured values in form of graph is shown in Fig.6.

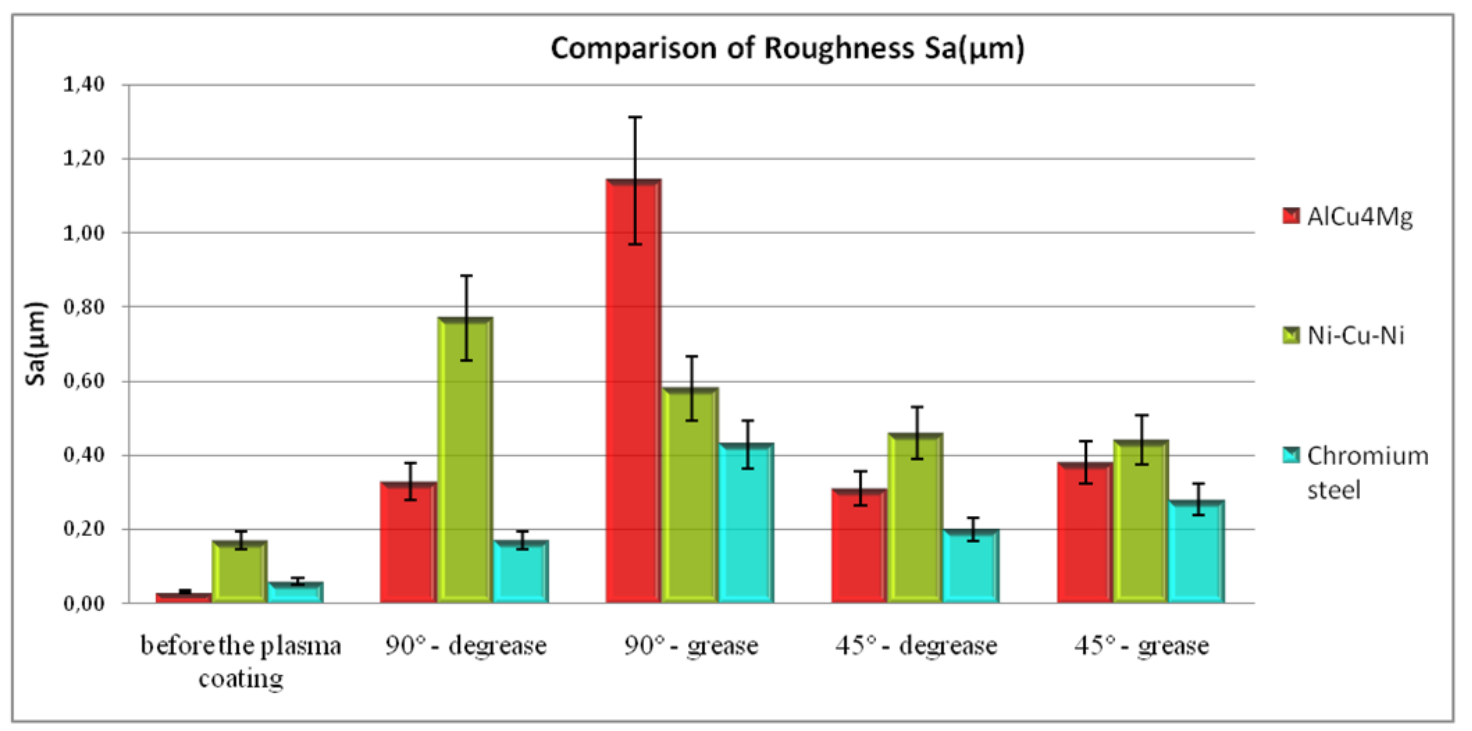

Figure 6. Representation of roughness results in graph 
The first look at the results indicates that the surface roughness of substrate is increased after application and removal of the multiple plasma layer for each tested material, but especially on lowhardness samples such as, e.g. AlCu4Mg with spray angle $90^{\circ}$. Samples with spray angle $45^{\circ}$ show less change of roughness. The result of the compared roughness is that, the harder material, the less is the increase on roughness.

\section{Duralumin (AlCu4Mg)}

Evaluation of samples $\mathrm{AlCu} 4 \mathrm{Mg}$ number 2-5 indicate a change in roughness, majorly on sample No. $3\left(90^{\circ}+\right.$ grease $)(\mathrm{Sa}=1.14 \mu \mathrm{m})$. Between sample no. 4 with $45^{\circ}$ angle of surface + degrease and no. 5 with $45^{\circ}+$ grease, small deviations $(\mathrm{Sa}=0,38 \mu \mathrm{m})$ were detected. Comparison of sample roughness before plasma spraying shows that the least increase was measured on sample no. $4\left(45^{\circ}+\right.$ degrease, $\mathrm{Sa}=$ $0.31 \mu \mathrm{m}$.) However, samples no. 2, 4, and 5 were measured and resulted in low deviations. Overall result depicts that greasing duralumin surface has negative influence on the surface roughness of samples after the plasma coating, resulting in increase in surface roughness as compared to degreased surface $(\mathrm{Sa}=0.33 \mu \mathrm{m}$ and $1.14 \mu \mathrm{m}$ for degreased and greased surface with angle of spraying $90^{\circ}$, respectively).

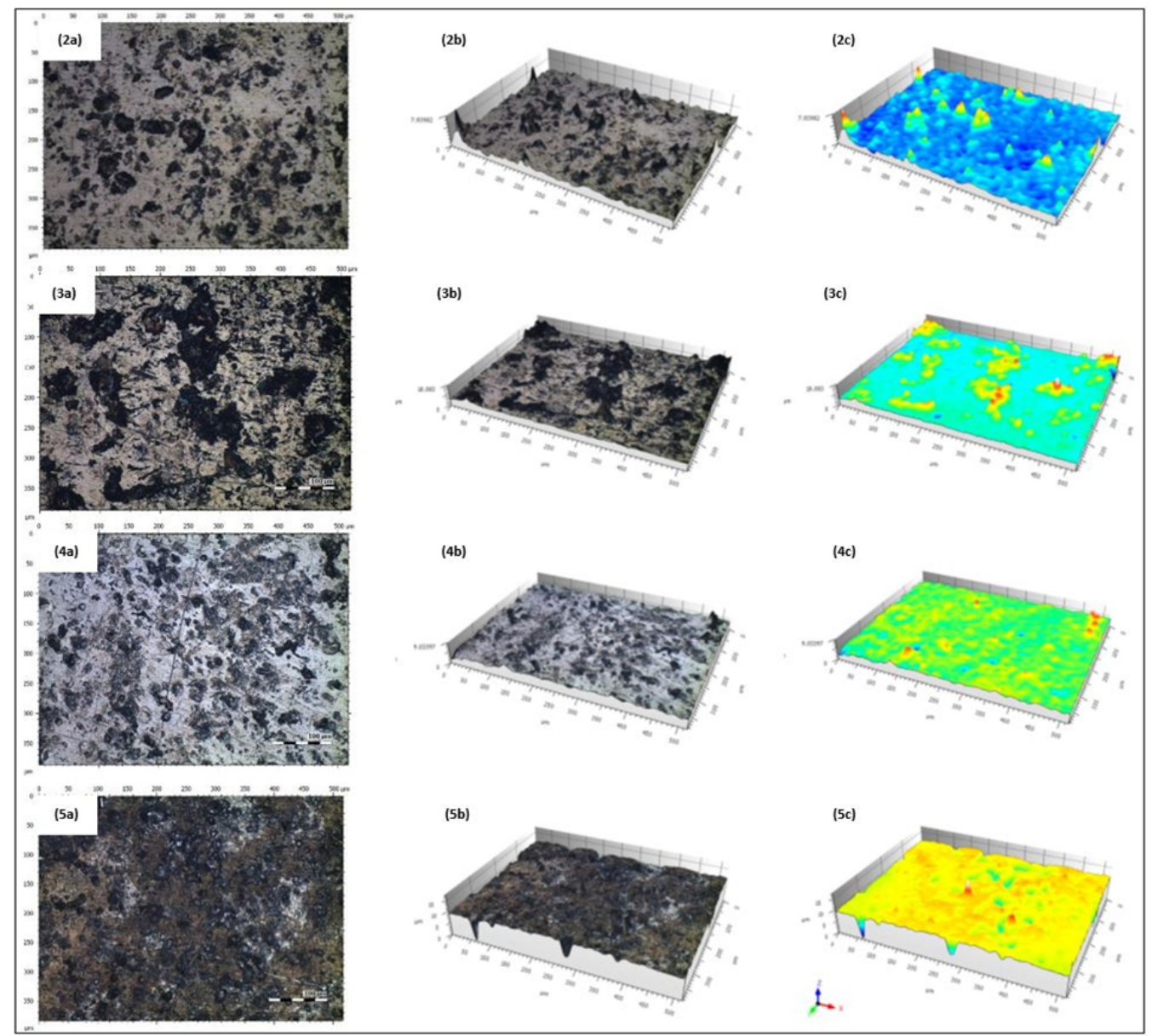

Figure 7. Measurement of parameter Sa of AlCu4Mg after plasma spraying and removal of coated layer (samples no. 2-

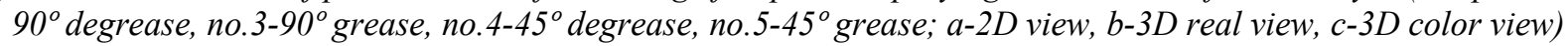

The result of roughness comparison of Duralumin samples is that the least increase of roughness had sample no. $4\left(45^{\circ}+\right.$ degrease $)$ and the highest increase of roughness had the sample no. $3\left(90^{\circ}+\right.$ grease). Overall result from measurement of roughness is that Duralumin $(\mathrm{AlCu} 4 \mathrm{Mg})$ is not suitable material for the production of cover mask because the increase of roughness on the sample from this material is very high.

\section{Nickel (Ni-Cu-Ni)}

Evaluation of samples coated Ni-Cu-Ni number 710 indicated a change in roughness mainly on samples with $90^{\circ}$ angle of surfaces. The highest increase of roughness was measured on sample no. 7 $\left(90^{\circ}+\right.$ degrease $)(\mathrm{Sa}=0.77 \mu \mathrm{m})$. The second highest increase was measured on sample no. $8\left(90^{\circ}+\right.$ grease) $(\mathrm{Sa}=0.58 \mu \mathrm{m})$. On samples with $45^{\circ}$ angle of surfaces were measured comparable values, $(\mathrm{Sa}=$ $0.46 \mu \mathrm{m}$ and $0.44 \mu \mathrm{m}$ for degreased and greased surface). 


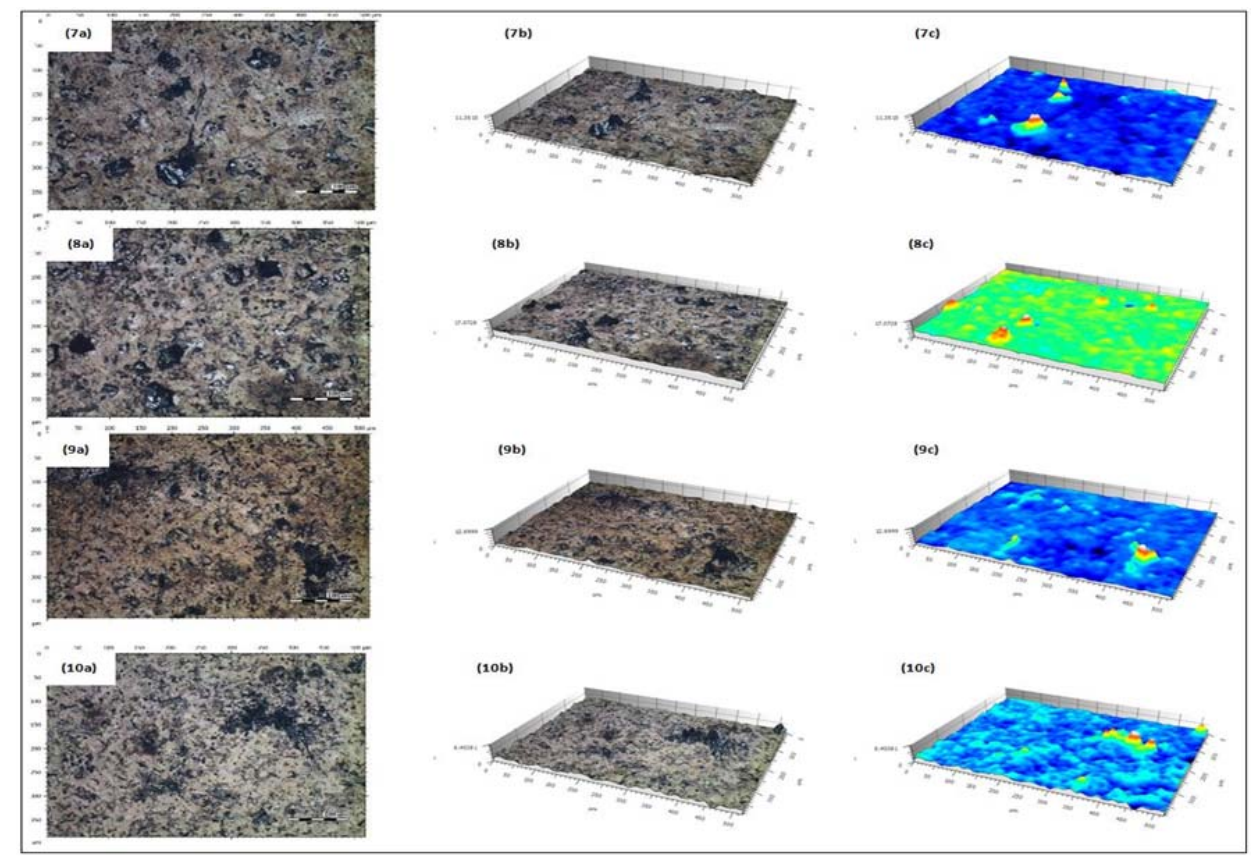

Figure 8. Measurement of parameter Sa Nickel after plasma spraying and removal of coated layer (samples no. 7-

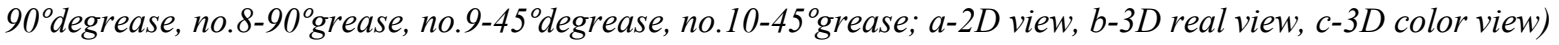

The result of roughness comparison of nickel (Ni$\mathrm{Cu}-\mathrm{Ni}$ ) samples is that the least increase of roughness had the samples no. $9\left(45^{\circ}+\right.$ degrease $)$ and no. 10 $\left(45^{\circ}+\right.$ grease $)$. The highest increase of roughness had sample no. $7\left(90^{\circ}+\right.$ degrease). The overall result from measurement of roughness is that nickel (Ni$\mathrm{Cu}-\mathrm{Ni}$ ) is not suitable material for the production of cover mask because the increase of roughness on all tested samples from this material is high.

\section{Chromium steel}

Evaluation of chromium steel samples no. 12-15 indicates a change in roughness of the material surface before and after plasma spraying process. The surface roughness was increased 3-5 times on samples 14 and 15 (both $45^{\circ}$ ) comparedto the uncoated samples $(\mathrm{Sa}=0.20 \mu \mathrm{m}$ and $0.28 \mu \mathrm{m})$. The highest increase of roughness (nine times) was measured on sample no. $13\left(90^{\circ}+\right.$ grease $)(\mathrm{Sa}=$ $0.43 \mu \mathrm{m})$. Sample no.12 $\left(90^{\circ}+\right.$ degrease; $\mathrm{Sa}=$ $0.17 \mu \mathrm{m}$ ) showed the minimum increase of roughness compared to sample before plasma spraying.

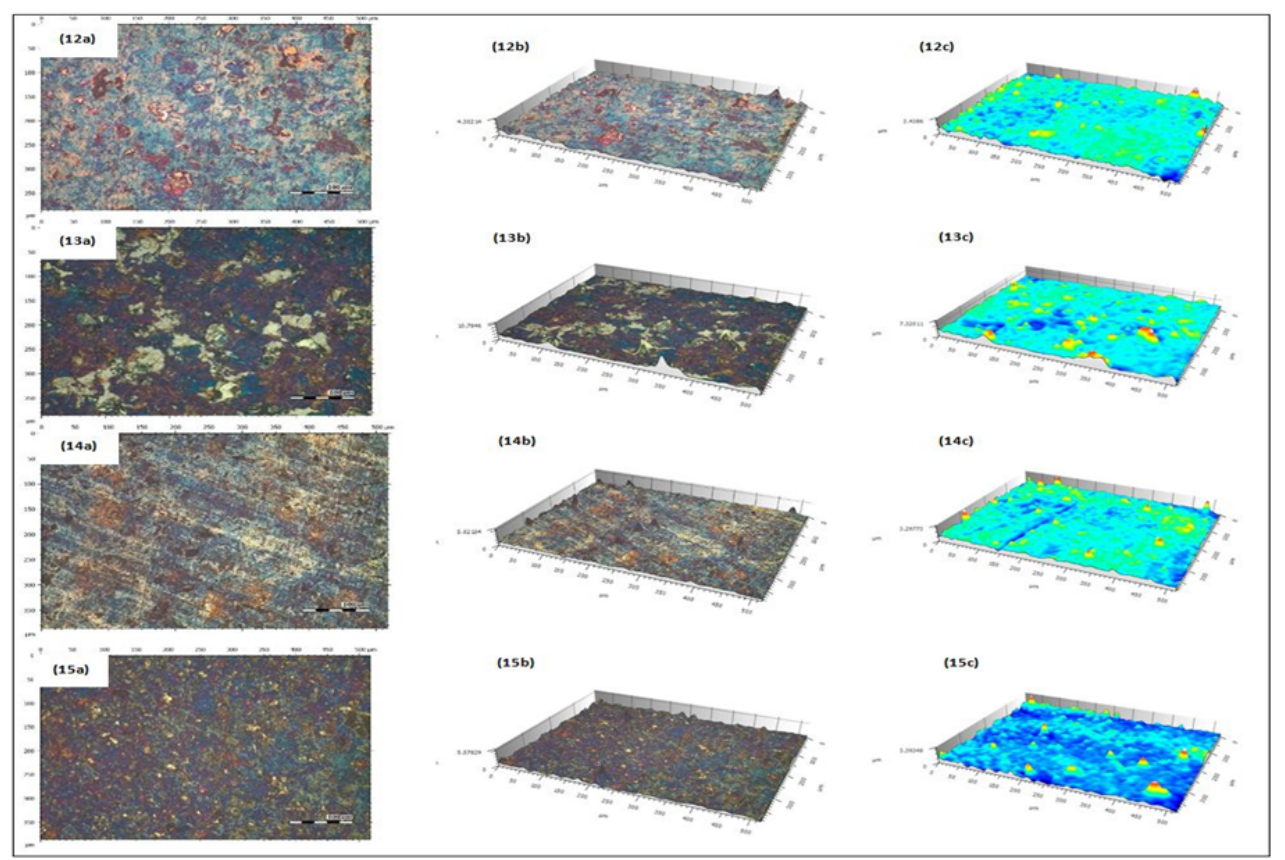

Figure 9. Measurement of parameter Sa of Chromium steel after plasma spraying and removal coated layer (samples

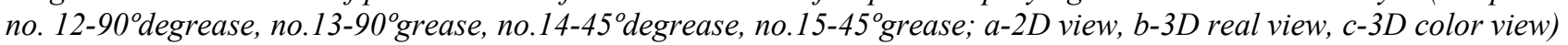


The result of roughness comparison of chromium steel samples is that the least increase of roughness had sample no. $12\left(90^{\circ}+\right.$ degrease $)$. The highest increase of roughness had sample no. $13\left(90^{\circ}+\right.$ grease). The results of samples from this material also confirm negative effect of grease surface on roughness, similar as material $\mathrm{AlCu} 4 \mathrm{Mg}$. Samples with greased surface had higher values of roughness than samples with degreased surface.

The overall result from measurement of roughness is that chromium steel is suitable material (it is the best material among the tested ones) for the production of cover mask because the increase of roughness on all tested samples from this material is low.
The most suitable version of surface for the material chromium steel is degreased surface with $90^{\circ}$ angle of surface.

\subsection{Microhardness}

Comparison of all tested materials for the parameter $\mathrm{HVm}$ is shown in Fig. 10. Measurements of the parameter $\mathrm{HVm}$ and surfaces are shown in Fig. 11-13.

The experiment was realized at the same plasma spraying parameters and the same distance from the plasma nozzle to the samples. Measurement of the microhardness on the surface of samples was realized on Duramin40. Average values were calculated from the 3 measurements (imprints) for each sample.

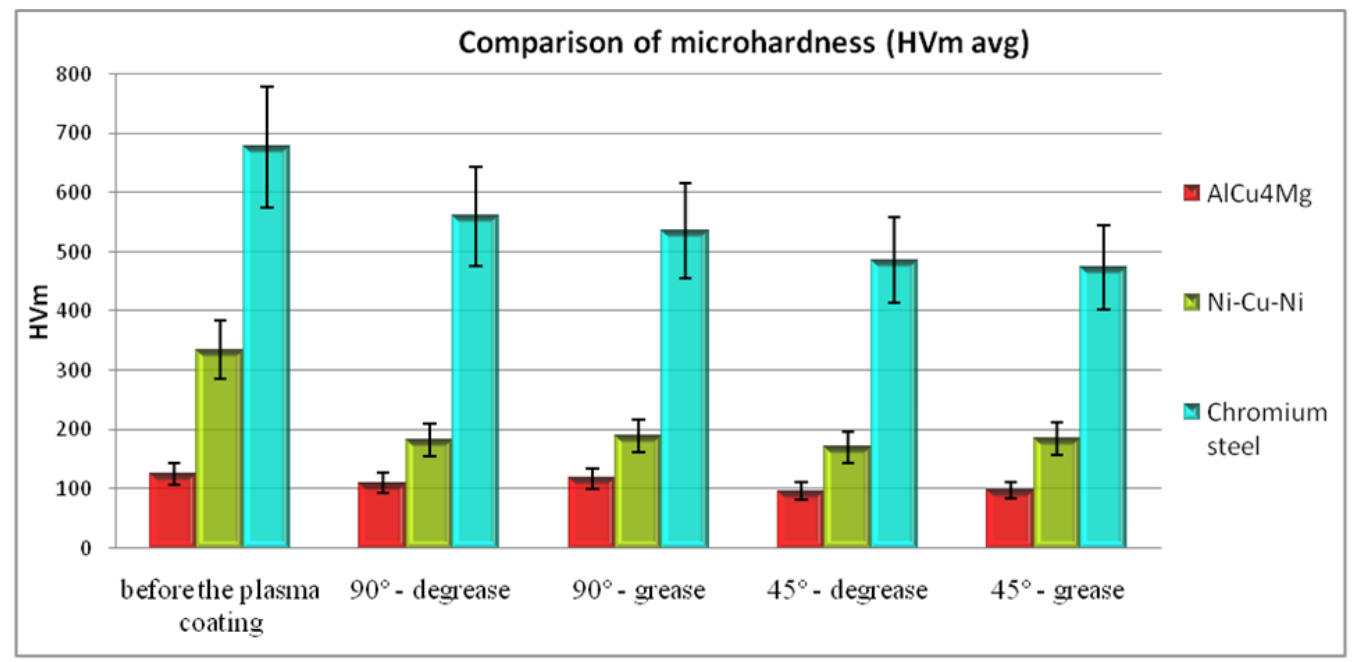

Figure 10. Representation of microhardness results in graph

The first look at the results indicates that the least change of microhardness was detected on the samples from the softest material, $\mathrm{AlCu} 4 \mathrm{Mg}$, the largest change was detected on samples from $\mathrm{Ni}-\mathrm{Cu}-$ Ni. The hardest material, chromium steel, shows the greatest change on samples with $45^{\circ}$ angle of surface.

For measurement and automatic calculation on Duramin-40 was used 50 and 10 times zoom depending on the material hardness. The automatic calculation was performed on the basis of the measured dimensions of the imprints. Mean values of microhardness were calculated from 3 measurements (imprints).

\section{Duralumin (AICu4Mg)}

Evaluation of duralumin samples number 2-5 did not show a change of surface microhardness by influence of plasma spraying. Microhardness of sample before plasma spraying was HVmavg = $128,62 \mathrm{HV}$.Between $90^{\circ}$ and $45^{\circ}$ samples and between samples with greased and degreased surfaces were measured minimal deviations. Samples no. 4 and no. $5\left(45^{\circ}+\right.$ degrease, $\mathrm{HVmavg}=96,3 \mathrm{HV}$ and $45^{\circ}$ +grease, HVmavg $=97,7 \mathrm{HV}$ ) had similar and higher decrease of microhardness compared with samples uncoated by plasma spraying. The lowest decrease of microhardness was measured on sample no. $3\left(90^{\circ}+\right.$ grease $)(\mathrm{HVmavg}=117,9 \mathrm{HV})$.

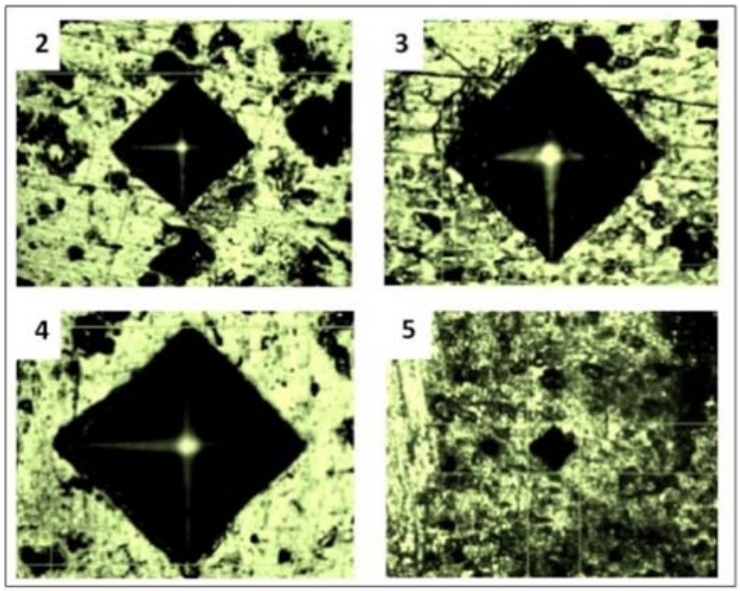

Figure 11. Image of microhardness measurement of AlCu4Mg after plasma spraying and removal of coated

layer - imprints (samples no.2- 90degrease, no.3$90^{\circ}$ grease, no. $4-45^{\circ}$ degrease, no. $5-45^{\circ}$ grease) 
The result of compared microhardness of Duralumin $(\mathrm{AlCu} 4 \mathrm{Mg})$ samples is that, the decrease of microhardness was low on all samples, compared to the microhardness before plasma spraying. Effect of spraying angle and surface cleanliness was not significant.

\section{Nickel (Ni-Cu-Ni)}

The evaluation of coated Ni-Cu-Ni samples no. 610 indicates significant reduction of microhardness values. Microhardness of sample before plasma spraying was HVmavg = 335,17HV.Every sample from this substrate materials had similar reduction of microhardness. The lowest reduction of microhardness was measured on sample no. $8\left(90^{\circ}+\right.$ grease) $($ HVmavg $=189,8 \mathrm{HV})$. The highest reduction of microhardness was measured on sample no. $9\left(45^{\circ}+\right.$ degrease $)(\mathrm{HVmavg}=170,2 \mathrm{HV})$. The hardness of the material was minimally affected by surface cleanliness (HVmavg $=183.8 \mathrm{HV}$ and $\mathrm{HVmavg}=189.8 \mathrm{HV}$ for degreased and greased surface with $90^{\circ}$ angle of surface and also for samples with $45^{\circ}$ angle of surface HVmavg $=170,2$ $\mathrm{HV}$ and $\mathrm{HVmavg}=184,4 \mathrm{HV}$ ).

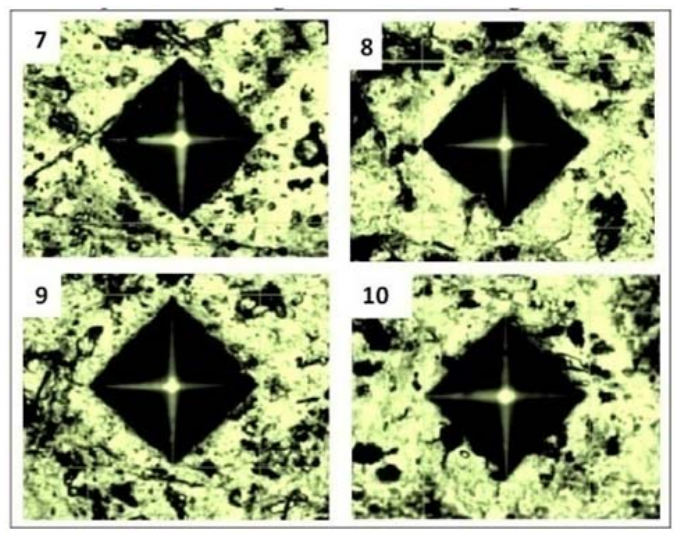

Figure 12. Image of microhardness measurement of nickel after plasma spraying and removal of coated layer imprints (samples no.7-90'degrease, no.8-90'grease,

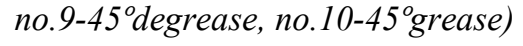

The result of compared microhardness of samples coated $\mathrm{Ni}-\mathrm{Cu}-\mathrm{Ni}$ is that the decrease of microhardness was high on all samples, compared to the microhardness before plasma spraying. The effect of spraying angle and surface cleanliness was not significant.

\section{Chromium steel}

Evaluation of experimental chromium steel samples (17 029) no. 12-15 indicates a change in microhardness of the material compared to the microhardness before plasma spraying. Microhardness of sample before plasma spraying was HVmavg $=676,12 \mathrm{HV}$. The highest reduction of microhardness was measured on sample no. $15\left(45^{\circ}\right.$ + grease) $($ HVmavg $=474,3 \mathrm{HV})$. The lowest reduction of microhardness was measured on sample no. $12\left(90^{\circ}+\right.$ degrease $)(\mathrm{HV}$ mavg $=560,4 \mathrm{HV})$.

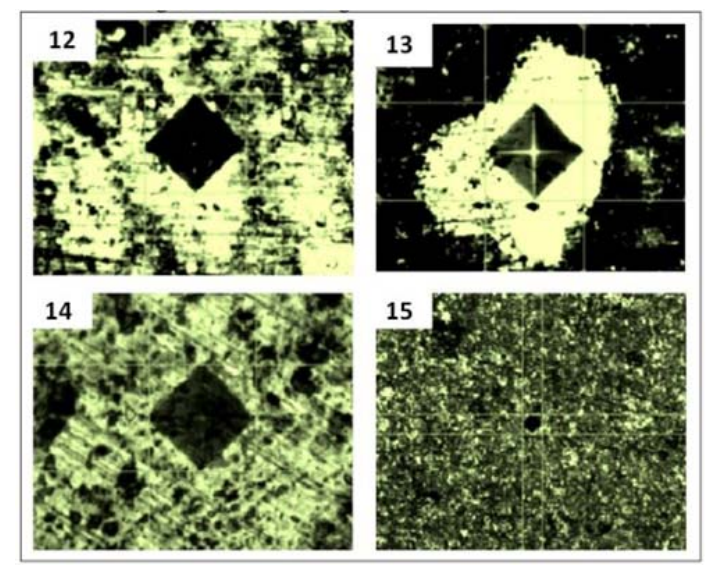

Figure 13. Image of microhardness measurement of chromium steel after plasma spraying and removal of coated layer - imprints (samples no. 12-90'degrease,

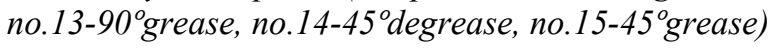

The result of microhardness comparison of chromium steel samples is that the decrease of microhardness was not very high, compared to the microhardness before plasma spraying. The effect of spraying angle and surface cleanliness was significant. Grease on sample surface decreases the value of microhardness more than degrease surface. The angle of surface $45^{\circ}$ decreases the value of microhardness more than $90^{\circ}$ of the angle of surface.

Overall results show that the high-hard material such as chromium steel has very good resistance to surface changes of microhardness after multiple plasma spraying. On the other hand, a protective coating such as e.g., Ni-Cu-Ni does not show sufficient resistance for surface microhardness changes. The lowest decrease of $\mathrm{HVm}$ from tested materials was recorded for samples from $\mathrm{AlCu} 4 \mathrm{Mg} 1$, but this result was caused by overall very low value of duralumin microhardness.

\subsection{SEM Observation of the Deposited Layer}

Surface morphology of deposited layer of $\mathrm{NiCr}$ on different substrate such as $\mathrm{AlCu} 4 \mathrm{Mg} 1$, nickel and chromium steel were observed using scanning electron microscopy. Images of the deposited layers were captured for in depth observation of the interface of the deposited layer on different substrates.
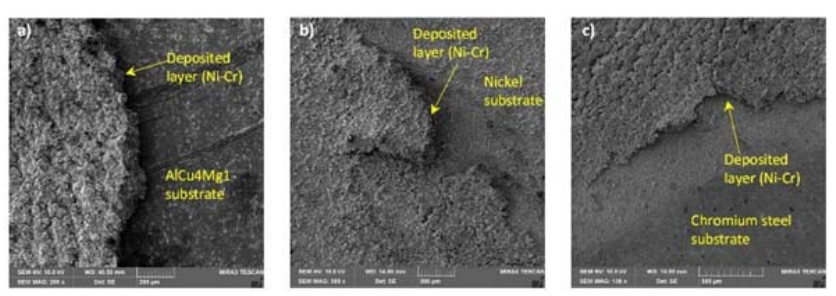

Figure 14. SEM images of the deposited layer on a) AlCu4Mg1 b) Nickel c) Chromium steel 
SEM images of $\mathrm{NiCr}$ deposition at $90^{\circ}$ surface angle with degreased surface cleanliness on different substrate has been shown in Fig.14. Surface cracks and micro holes on the deposited layers are common feature observed on all the deposited layers. However, these surface irregularities are much more evident with substrate $\mathrm{AlCu} 4 \mathrm{Mg} 1$ and nickel than compared to chromium steel. These also validate the observation of the measured surface roughness of the samples after removed layers as shown in Tab.3. (Sa $=0,33 \mu \mathrm{m}, 0,77 \mu \mathrm{m}$ and $0,17 \mu \mathrm{m}$ for $\mathrm{AlCu} 4 \mathrm{Mg} 1$, nickel and chromium steel respectively). It shows poor surface finish or unsuitable material for $\mathrm{ALCu} 4 \mathrm{Mg} 1$ and nickel as compared to chromium steel. The surface hardness of the samples is also affected by the pores or uneven structure of the layers leading to different values of hardness. Tab. 3. shows the values of HVmavg for different surfaces $/$ deposition layers (HVmavg $=110,27 \mathrm{HV}, 183,8$ $\mathrm{HV}, 560.4 \mathrm{HV}$ for $\mathrm{AlCu} 4 \mathrm{Mg} 1$, nickel and chromium steel respectively) which have similarity with the observed SEM surfaces.

\subsection{Frequency of Self-Peeling Out}

Testing the frequency of self-peeling out was performed on samples chromium steel with $90^{\circ}$ and $45^{\circ}$ angle of surface. Chromium steel was selected for this test because this material was the most suitable among the tested materials in comparison to roughness and microhardness. Cleanliness had not significant effect on the change of roughness and microhardness so the samples were tested only with degreased surface. Sample chromium steel with $90^{\circ}$ was selected as the best version from all tested versions on the parameters roughness and microhardness.
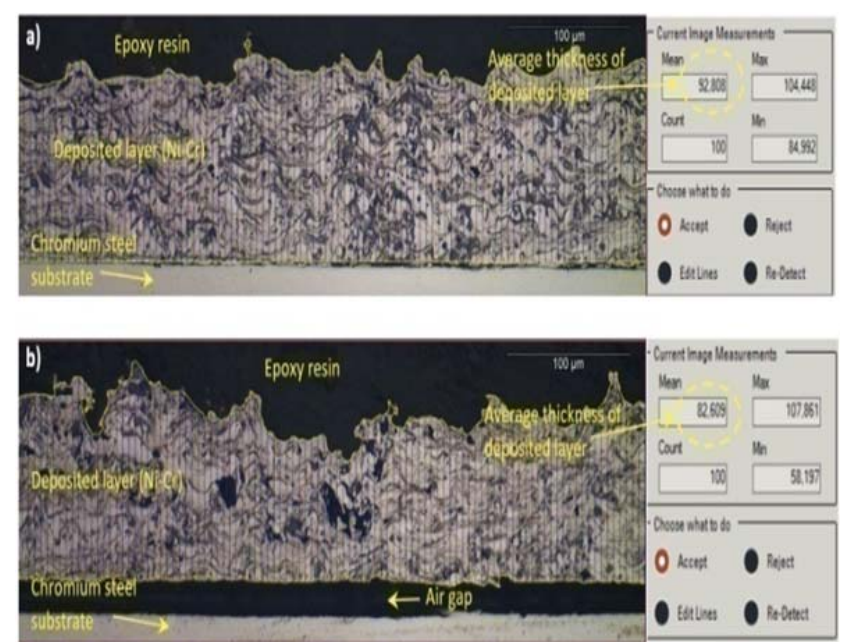

Figure 15. Cross section of self-peel off layers after 6-time spraying plasma layer; a) Chromium steel sample with spray angle $90^{\circ}$ and degrease of surface b) Chromium steel sample with spray angle $45^{\circ}$ and degrease of surface
The surface of the substrate in this case was sprayed 6-times (only 6-times, because on sample (b) already started process of self-peeling in this time). Sample(a) withangle $90^{\circ}$ and degrease of surface had average thickness of deposited layer $92,8 \mu \mathrm{m}$. The coated layer is not self-peel out from substrate surface and the surface of the layer is relatively even surface in comparison with the second sample. The second sample (b) with angle $45^{\circ}$ and degrease of surface had lower average thickness of deposited layer $82,6 \mu \mathrm{m}$. The coated layer is self-peel out from substrate and the surface of the layer is similar as the ridge.

The overall result shows that the angle of the surface has a significant effect on layer thickness, layer surface and mainly frequency of self-peeling out of multilayer from substrate. Self-peeling of multilayer from substrate surface starts after approximately 6 times plasma spraying on sample with $45^{\circ}$ angle of surface, but on sample with $90^{\circ}$ angle of surface after approximately 10 times plasma spraying. It seems that the lifetime of material surface for cover mask is longer in case of $90^{\circ}$ angle of surface, because in this case it self-peels (repeated abrasion of substrate surface by new multiple layer) less frequently. When multilayer starts to self-peel, thickness of multilayer is in both cases very similar.

\section{Discussion and Conclusions}

Based on the all experimental observations, the following overall results and conclusions are as follows:

1. Overall result from measurement of roughness shows that chromium steel is suitable material (it is the best material among the tested materials) for the production of cover mask because roughness increase on all tested samples from this material is low. The most suitable version of surface for chromium steel is degrease surface with $90^{\circ}$ angle of surface.

2. Overall results from measurement of microhardness show that the high-hard material such as chromium steel has very good resistance to surface microhardness changes after multiple plasma spraying. On the other hand, a protective coating such as, e.g. Ni-Cu-Ni does not show sufficient resistance to surface microhardness changes. The lowest decrease of $\mathrm{HVm}$ from tested materials was recorded for samples from $\mathrm{AlCu} 4 \mathrm{Mg} 1$, but this result was caused by overall very low value of duralumin microhardness.

3. SEM observation of the deposited layer confirms previous results of roughness measurements and microhardness - chromium steel is the most suitable material among the materials tested for a production of cover mask. 
4. The comparison of self-peeling frequency confirms that the tested version of sample with $90^{\circ}$ angle of surface from chromium steel is the most suitable one among the versions for production of cover mask tested. The lifetime of cover mask is longer in case of $90^{\circ}$ angle of surface, because in this case it self-peels (repeated abrasion of substrate surface by new multiple layer) less frequently than the version with $45^{\circ}$ angle. When multilayer starts to selfpeel, the thickness of the multilayer is in both cases $\left(90^{\circ}\right.$ vs. $\left.45^{\circ}\right)$ very similar. The difference of the effect on the internal dimensions of the cover mask and also on required dimensions of spraying areas on the tube is minimal between these two version.
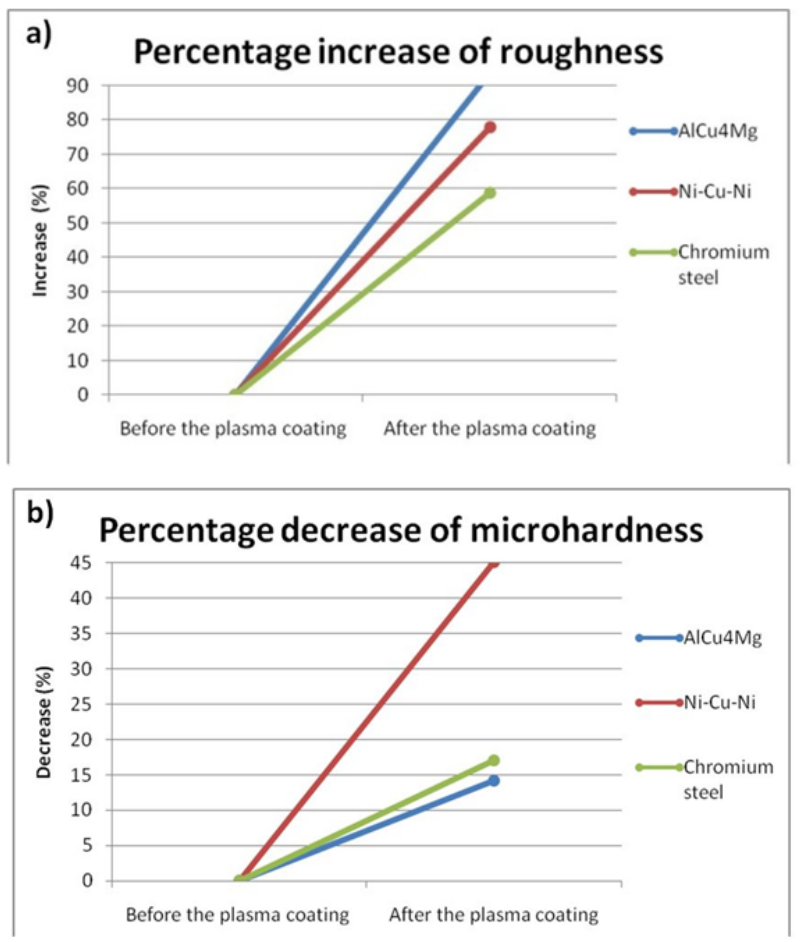

Figure 16. Graphical comparison of (a)-percentage increase of roughness (measured values: Chromium steel $=64,71 \%$; $\mathrm{Ni}-\mathrm{Cu}-\mathrm{Ni}=77,92 \% ; \mathrm{AlCu} 4 \mathrm{Mg}=90,61 \%)$, (b)-percent decrease of microhardness (measured values: Chromium steel $=17,29 \%$; $\mathrm{Ni}-\mathrm{Cu}-\mathrm{Ni}=45,15 \%$; AlCu $4 \mathrm{Mg}=11,55 \%$ ) on samples with $90^{\circ}$ angle of surface and degrease of surface

5. The suitability of the chromium steel material selection was also confirmed as seen in the graphical representation - Fig.16. The percentage increase of roughness: chromium steel $=64,71 \%$, has the least increase. Reduction of microhardness: $\mathrm{AlCu} 4 \mathrm{Mg}=11,55 \%$ and chromium steel $=17,29 \%$ have the least decrease (comparable values). Values were compared on samples with $90^{\circ}$ angle of surface and degrease surface, because this version of samples showed the best results.

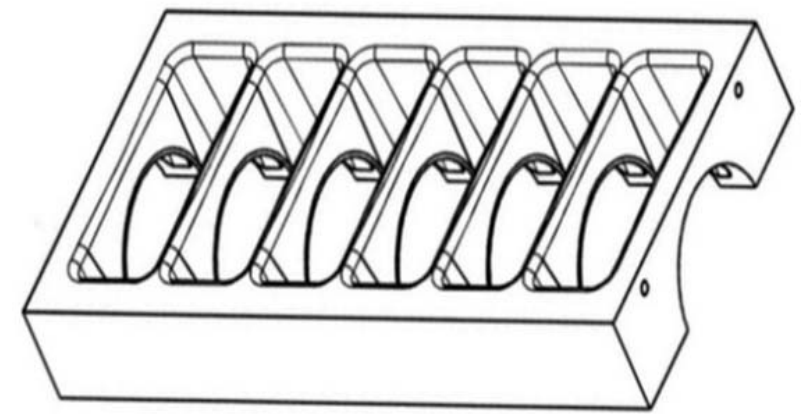

a)

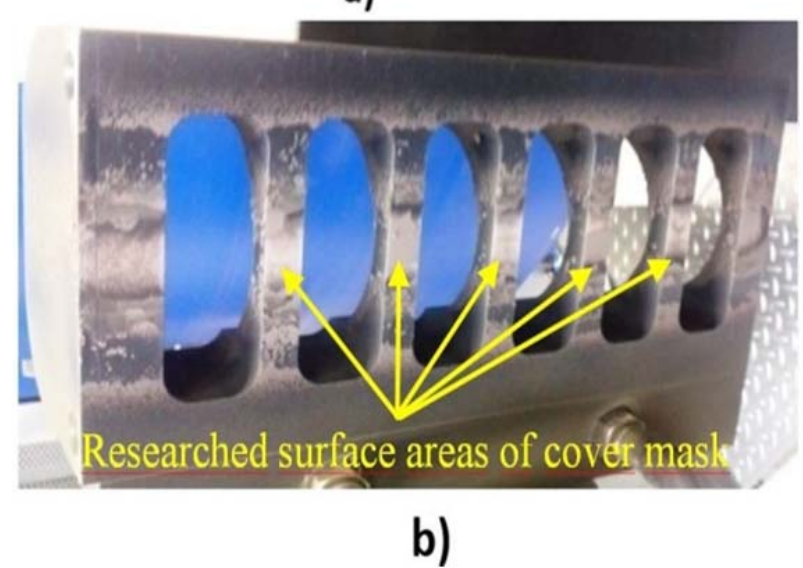

Figure 17. Suggestion cover mask from chromium steel for masking a product (tube) before plasma spraying; a) one of the first designs of cover mask before research in this article; b) design after research in this article

\section{Conclusion}

The version of sample chromium steel with $90^{\circ}$ angle and degrease of surface shows the least increase of roughness and decrease of microhardness after multiple plasma spraying with respect to the longest life of the mask. This version is the best for the life time of the cover mask, because minimal change of roughness and hardness is the best assumption for stability of frequency of self-peeling (each 10-12 spraying cycles). The stability of frequency of self-peeling guarantees correct dimension of the areas on the tube which must not be coated.

The results were partially verified in practice in serial conditions of plasma spraying. The cover mask had no difficulties with more then 1000-time plasma spraying without seriously exceeding the dimensional tolerance of the masking area on the tube. A design change of the cover mask in practice before and after research in this article is shown in Fig.17.Thechange of the material and angle of plasma spraying was also implemented. 


\section{Acknowledgement}

This study was supported by VEGA 1/0096/18.

\section{References}

[1]. Aubrecht, V. (2003). Technické aplikace plazmatu: současný stav, trendy vývoje a výuka. Vutium.

[2]. Ambrož, O., \& Kašpar, J. (1990). Žárové nástřiky a jejich prưmyslové využití. Praha: SNTL, $320 \mathrm{~s}$.

[3]. Tucker Jr, R. C. (2013). ASM Handbook, Volume 5A, Thermal Spray Technology. plastics industry, 335, 336.

[4]. Steffens, H. D., \& Nassenstein, K. (1993). Thermal spraying: a review of 1993. Powder Metallurgy International, 25(6), 280-284.

[5]. Suryanarayanan, R. (1993). Plasma spraying: theory and applications. World Scientific.

[6]. Westergård, R., Axén, N., Wiklund, U., \& Hogmark, S. (2000). An evaluation of plasma sprayed ceramic coatings by erosion, abrasion and bend testing. Wear, 246(1-2), 12-19.

[7]. Jankura, D., \& Papcun, P. (2009). Evaluation of structure of ceramics and composite coatings prepared by heating spraying. Zeszyty Naukowe Politechniki Rzeszowskiej. Mechanika, 78(270), 25-29.

[8]. Houdková Šimůnková, Š., Enžl, R., \& Bláhova, O., (2003). Žárové nástřiky: moderní technologie povrchových úprav.

[9]. Matthews, S., James, B., \& Hyland, M. (2009). The role of microstructure in the mechanism of high velocity erosion of $\mathrm{Cr} 3 \mathrm{C} 2-\mathrm{NiCr}$ thermal spray coatings: Part 1-As-sprayed coatings. Surface and Coatings Technology, 203(8), 1086-1093.
[10]. Sidhu, B. S., \& Prakash, S. (2006). Nickel-chromium plasma spray coatings: A way to enhance degradation resistance of boiler tube steels in boiler environment. Journal of thermal spray technology, 15(1), 131-140.

[11]. az, M. Y., Shukrullah, S., Ghaffar, A., \& Rehman, N. U. (2014). Development of simple designs of multitip probe diagnostic systems for RF plasma characterization. The Scientific World Journal, 2014.

[12]. Díaz-Cabrera, J. M., Palop, J. F., Crespo, R. M., Hernández, M. A., Tejero-del-Caz, A., \& Ballesteros, J. (2014). Virtual Instrument for automatic low temperature plasmas diagnostic considering finite positive ion temperature. Measurement, 55, 66-73.

[13]. Fauchais, P. L., Heberlein, J. V., \& Boulos, M. I. (2014). Thermal spray fundamentals: from powder to part. Springer Science \& Business Media.

[14]. Pawlowski, L. (2008). The science and engineering of thermal spray coatings. John Wiley \& Sons.

[15]. Skočovský, P., \& Konečná, R. (1996). Nové konštrukčné materiály: Vybrané kapitoly 2. Žilinská univerzita.

[16]. Svenson, E. (2006). Durachrome hard chromium plating. Surface Finishing Technology

[17]. Lesage, J., \& Chicot, D. (2002). Role of residual stresses on interface toughness of thermally sprayed coatings. Thin Solid Films, 415(1-2), 143-150.

[18]. Kužma, J., Krescanko, M., \& Hloch, S. (2019). Change of the Substrate Surface After Removal Multiple Plasma Spraying Layers. In Advances in Manufacturing Engineering and Materials (pp. 351361). Springer, Cham. 